\title{
Reconfigurations of the social sphere in Brejo da Paraíba in the 2lst century: imprints of plantations in Latin America
}

\section{Patrícia Alves Ramiro*}

\begin{abstract}
The research project "Reconfigurations of the social sphere in Brejo of Paraíba in the 21st century" looks into the new social arrangements in that region of northeastern Brazil, which stem from the abrupt changes in the context that was prevalent in the early 1990s, triggered by the closure of sugarcane mills, following the bankruptcy declared by Santa Maria processing plant. Included in a broader debate regarding the imprints left by centuries on social structures organized around export-led plantations in Latin America, this is a collective research project that aims to inquire into different conversion strategies in comparison with the previous position occupied by social actors in the golden period of sugarcane production.
\end{abstract}

Keywords: sugarcane agribusiness, Brazilian Northeast, plantations.

\footnotetext{
* Federal University of Paraíba.
} 


\section{Reconfigurações do espaço social do Brejo paraibano no século XXI: as marcas das plantations na América Latina}

\section{Resumo}

O projeto de pesquisa "Reconfigurações do espaço social do brejo paraibano no século XXI" visa compreender as novas configurações sociais desta região do Nordeste do Brasil, decorrentes das transformações abruptas vivenciadas, devido ao encerramento da produção sucroalcooleira, no mundo social que a compunha no início da década de 1990, após decreto de falência da usina Santa Maria. Inserido num debate mais amplo referente às marcas deixadas por séculos em espaços sociais dedicados às plantations com vocação exportadora na América Latina, trata-se de projeto coletivo de pesquisa visando dar conta de diferentes estratégias de reconversão em conformidade com a posição anterior ocupada pelos atores sociais no período áureo da produção canavieira.

Palavras-chave: agroindústria canavieira, Nordeste, plantations.

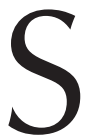

ince the seventeenth century colonial times in Brazil, agricultural investments in sugarcane plantations aimed at the international market have been a key element to both shape and understand Brazilian society in many aspects - be it economic or social, cultural, environmental or political (Freyre, 1989; Holanda, 1936). The imprints left by it still resonates in the new current configurations, even in places that show a significant decline in this agro-industrial structure due to closure or bankruptcy of sugarcane mills, as is the case in the Northeast region of the country.

Included in a broader debate regarding the impacts of plantations in the so-called new world built upon the triad of latifundium, monoculture and slavery, the research project "Reconfigurations of the social sphere in Brejo da Paraíba in the 21st century" aims to understand part of the abrupt changes triggered by the closure of sugarcane production and processing plants. It draws on the empirical case of Usina Santa Maria (Santa Maria sugarcane processing plant), located in the Brejo region, in the northeastern 
state of Paraíba, Brazil. Founded in 1931, the plant had an area of 3,453 hectares distributed over the municipalities of Areia, Pilões, and Serraria. In 1992, it was declared bankrupt, causing thousands of people, who either directly or indirectly relied on its operation, to be faced with the challenge of creating reconversion strategies.

It is worth highlighting that this project is the continuance of anthropological reflections by researchers linked to the Graduate Program in Social Anthropology of the National Museum (PPGAS-MN/UFRJ) carried out within the scope of the project Employment and Socioeconomic Change in the Northeast, directed by Moacir Palmeira (1977). Among the academic production of that team, two authors have focused on the region now revisited. Afrânio Garcia Jr. and Marie France Garcia Parpet (collaborators of this current project) ${ }^{1}$ have been in Brejo da Paraiba in the late $1970 \mathrm{~s}$ and mid-1980s, when Santa Maria mill was at the peak of its production (Garcia Jr., 1989; Garcia Parpet, 1992).

Although production level was directly related to government subsidies granted in the scope of the National Program for Sugarcane Improvement (Planalsucar) and the National Program on Alcohol Production (Proálcool), then in force, there was nothing that suggested this world was about to collapse. But now, forty years later, we are faced with the ferocity and startling speed of remarkable changes in that social sphere, whose tip of the iceberg lies in the bankruptcy of Santa Maria mill.

From a wide range of new arrangements for social reproduction that emerged in the region, our inquiry focuses primarily on two situations found in distinct social positions in that region. On the one hand, the mill's lands were expropriated and redistributed under the Agrarian Reform program, giving rise to ten rural settlements composed of 420 families of former residents of these lands. On the other hand, some plantation

1 In addition to contributions from Afranio Garcia Jr. and Marie-France Garcia Parpet, researchers in Centre Européen de Sociologie et de Science Politique (CESSP) at the École des Hautes Études en Sciences Sociales, (EHESS), also Marilda Aparecida de Menezes, and undergraduate and graduate students from the Federal University of Paraíba (UFPB) and the Federal University of Campina Grande (UFCG) take part in this study. 
owners and their heirs sought conversion strategies to maintain or improve their position in the social sphere, since most of them had been sugarcane suppliers for the mill. In a broad perspective, we seek to understand the transformations in the material and symbolic practices of social actors in the region. Or, in other words, we look into what changes in the social life of these people and what kind of behavior are required to manage their lives in the current situation.

We'll start with what we might call "reconversion of those from grassroots". It was the crisis of social reproduction of those from the top in the social structure - in this case, mill owners and plantation owners who lived from sugarcane production for supplying this agroindustry -, brought about by the bankruptcy of Usina Santa Maria, that engendered the possibility of changing the situation of grassroots people through agrarian reform. The settled families belonged to the social category of residents of lands owned by the mill. A category that replaces that of slaves in northeastern Brazil, since it denotes a relationship marked by the subjection of the residents to the mill owner, to whom they owe loyalty and hard work. A relationship that started when they asked some plantation owner for "a dwelling", as the usufruct of a small plot of land (called roçado) was often the last chance for many to escape privation and hunger, which was repaid with work in the plantations (Palmeira, 2009; Heredia, 1976).

In such relationship, that Garcia Jr. (1989) called personalized domination, this poor and mostly uneducated population depended on the landowners for supplying their basic needs, from dwelling to firewood and access to water. For these people, although agrarian reform means an upward mobility, it also means the experience of an uprooting process to reconstruct subjective worlds, objectively constructed in the present.

The new situation as "settlers" requires them new mental and practical investments in their daily lives. It is a situation that places them within the dynamics of a market economy, in which they have the need (and the power) to decide on their production (what and how to plant) and selling forms - to dealers, via public policies as the National School Feeding Program 
(PNAE) and the Food Acquisition Program (PAA), ${ }^{2}$ at farmers' markets etc. Furthermore, they begin to compete with other small local farmers in the local and regional market, a new situation for which not all of them are ready.

The mill's bankruptcy also causes metamorphoses in the "world of Casa Grande" (plantation owners). One of the strategies observed among this elite group was the attempt at social reconversion through the symbolic valorization of "artisanal cachaça", following the path trodden by other Brazilian states such as Minas Gerais and Rio de Janeiro. We then focused on the change of a product appeared in the Brazilian Northeast in the 1970s as a "[...] relic from a dead past" (Correia de Andrade, 1974, p. 181 ) into a valued product in the present, symbol of both the successful conversion trajectories of part of the mill owners of the region and of the transformation of a product deemed popular (a drink originally associated with slaves and later with popular classes) into an elite drink.

As we presented in some studies (Garcia Parpet; Ramiro, 2018; Ramiro; Garcia Parpet, 2019a; 2019b), this process of recovery of the craft liquor draws on both incorporation of new techniques in the production process, particularly, the use of copper still, and the design of new packaging and novel consumption practices. One of the examples resides in the creation of porcelain bottles resembling traditional tableware used in the homes of agrarian elites in the past and the emergence of bottles with designs that recall well-known whiskey brands, such as Johnnie Walker. With regard to consumption, the novelty introduced by producers is the consumption of cachaça stored at low temperatures, like vodka. From a sociological perspective, all of these conversions, regardless of where they occur, involve individual, family and collective trajectories that require our attention to life

2 PAA and PNAE are public policies implemented during the government of Luis Inacio Lula da Silva. The PAA was created in 2003 and involves government procurement for direct acquisition of produce from family farms for distribution to underprivileged groups. PNAE, created by Law No. 11947 of 16/06/2009, establishes that 30\% of government procurement to supply school feeding shall be purchased from family farming and earmarked for public education establishments. After the election of the extreme right-wing government, in 2019, these programs have been under severe threat, despite the importance already shown by Medeiros et al. (2014). 
stories and all conflicts, difficulties, deaths and weddings that organize this social sphere, so that to overcome an economistic analysis of conversions that involve a whole social structure which is profoundly altered.

The current stage of the research involves the construction by the research team of the particular empirical objects, all of which, however, emerge from this broad collective inquiry, here briefly presented. Organic cachaça, quality seals, construction of both tangible and intangible heritage and tourism are subjects that have strongly mobilized local elites, and that still spur us to understand this reality. As regards popular classes, research interest lies in farmers' markets and in changes in gender and generational relations regarding the division of labor, as well as in recent forms of sociability arising from access to school education for children, in addition to migration practices in the present.

Finally, this project will also produce other individual ethnographies that may reveal what is recurrent and what varies contingently in the perceptions of different social agents about the universe where they are placed. Therefore, it will continue to contribute to the broader debate relating the imprints left by centuries under the domination by export-led plantations in Latin America (Rogers, 2010; Monzote, 2008), a highly important subject for understanding the persistence of deep social inequalities.

Patrícia Alves Ramiro holds a PhD in Sociology, is a professor at the Federal University of Paraíba and leads the "Identity and Memories of the rural and urban popular classes" research team for CNPq.

$\triangle$ patriciaalvesramiro@gmail.com 


\section{References}

1. CORREIA DE ANDRADE, Manuel. A cidade e o campo no Brasil. São Paulo: Brasiliense, 1974.

2. FREYRE, Gilberto. Nordeste: aspectos da influência da cana sobre a vida e a paisagem do Nordeste do Brasil. 6. ed. Rio de Janeiro: Record, 1989.

3. GARCIA JR., Afrânio. O Sul: caminho do roçado. Brasília: MCT, CNPq, 1989.

4. GARCIA PARPET, Marie-France. O segundo sexo do comércio: Camponesas e negócio no Nordeste do Brasil. Revista brasileira de Ciências Sociais, n. 19, 1992.

5. GARCIA PARPET, Marie-France; RAMIRO, Patrícia Alves. La "cachaça" : boisson d'esclave ou boisson d'élite? Reconversions de "senhores de engenho" do Brejo de l'État de Paraíba au Brésil. Psihologia Sociala, n. 42 II, p. 75-92, 2018.

6. HEREDIA, Beatriz A. de. Formas de dominação e espaço social: a modernização da agroindústria canavieira em Alagoas. São Paulo: Marco Zero/ MCT/CNPq, 1988.

7. HOLANDA, Sérgio Buarque de. Raízes do Brasil. 26. ed. São Paulo: Companhia das Letras, 1995.

8. MEDEIROS, Leonilde S. et. al. O Programa de Aquisição de Alimentos (PAA) em assentamentos de reforma agrária: implantação, impactos e perspectivas. In: BRASIL - Ministério do Desenvolvimento Social e Combate à Fome. PAA: 10 anos de aquisição de alimentos. Brasília: MDS; Secretaria Nacional de Segurança Alimentar e Nutricional, 2014. p. 152-181.

9. MONZOTE, Reinaldo F. From rainforest to cane field in Cuba: an environmental history since 1492. Chapel Hill: The University of North Carolina Press, 2008.

10. PALMEIRA, Moacir G. S. Casa e trabalho: nota sobre as relações sociais na plantation tradicional. In: WELCH, C. A. et al. (orgs.). Camponeses brasileiros. São Paulo: Editora UNESP/NEAD, 2009. p. 203-215.

11. PALMEIRA, Moacir G. S. et al. Emprego e mudança sócio-econômica no Nordeste. Anuário Antropológico, n. 76, p. 207-292, 1977.

12. RAMIRO, Patrícia A., GARCIA PARPET, Marie-France. O valor do lugar: o turismo e a valorização simbólica da cachaça no brejo. In: RAMIRO, Patrícia A. (org.). Antropologia e turismo: coletânea franco-brasileira. João Pessoa: Editora UFPB, 2019a, p. 77-97.

13. RAMIRO, Patrícia A., GARCIA PARPET, Marie-France. Cachaça! A ressignificação de um produto "genuinamente" brasileiro. Revista Continente, n. 222, jun. 2019b. Disponível em: https://www.revistacontinente.com.br/ edicoes/222/cachaca--2

14. ROGERS, Thomas D. The deepest wounds: a labor and environmental history of sugar in northeast Brazil. Chapel Hill: University of North Carolina Press, 2010.

Received 12 May 2020.

Accepted 5 Feb. 2021. 
